\title{
Pathogenesis of Alfalfa mosaic virus in Soybean (Glycine max) and Expression of Chimeric Rabies Peptide in Virus-Infected Soybean Plants
}

\author{
Nina Fleysh, Deepali Deka, Maria Drath, Hilary Koprowski, and Vidadi Yusibov
}

Biotechnology Foundation Laboratories at Thomas Jefferson University, Philadelphia, PA 19107.

Current address of V. Yusibov: Fraunhofer Center for Molecular Biotechnology, 15 Innovation Way, Room 125, Newark, DE 19711. Accepted for publication 30 May 2001.

\begin{abstract}
Fleysh, N., Deka, D., Drath, M., Koprowski, H., and Yusibov, V. 2001. Pathogenesis of Alfalfa mosaic virus in soybean (Glycine max) and expression of chimeric rabies peptide in virus-infected soybean plants. Phytopathology 91:941-947.

Infection of soybean (Glycine max) plants inoculated with particles of Alfalfa mosaic virus (AlMV) isolate 425 at 12 days after germination was monitored throughout the life cycle of the plant (vegetative growth, flowering, seed formation, and seed maturation) by western blot analysis of tissue samples. At 8 to 10 days after inoculation, the upper uninoculated leaves showed symptoms of virus infection and accumulation of viral coat protein $(\mathrm{CP})$. Virus $\mathrm{CP}$ was detectable in leaves, stem, roots,

seedpods, and seed coat up to 45 days postinoculation (dpi), but only in the seedpod and seed coat at $65 \mathrm{dpi}$. No virus accumulation was detected in embryos and cotyledons at any time during infection, and no seed transmission of virus was observed. Soybean plants inoculated with recombinant AIMV passaged from upper uninoculated leaves of infected plants showed accumulation of full-length chimeric AlMV CP containing rabies antigen in systemically infected leaves and seed coat. These results suggest the potential usefulness of plants and plant viruses as vehicles for producing proteins of biomedical importance in a safe and inexpensive manner. Moreover, even the soybean seed coat, treated as waste tissue during conventional processing for oil and other products, may be utilized for the expression of value-added proteins.
\end{abstract}

Infection of alfalfa (Medicago sativa) with Alfalfa mosaic virus (AlMV) in the United States was first reported in 1931 (32). The virus belongs to the genus Ilarvirus and is a member of the family Bromoviridae. The genome of AlMV consists of three positivesense RNAs (RNAs 1 through 3). RNAs 1 and 2 encode replicase proteins P1 and P2, respectively (2), and RNA3 encodes the cellto-cell movement protein $\mathrm{P} 3(8,25)$. The virus coat protein $(\mathrm{CP})$ is translated from the subgenomic RNA4 synthesized from genomic RNA3 (3). AlMV depends on a functional P3 protein for cell-to-cell movement, whereas the $\mathrm{CP}$ is required throughout viral infection because of its role in genome activation to initiate the infection $(3,30,33,34)$, RNA replication $(6,29)$, virus assembly (12), stability of viral RNA $(13,21)$, long-distance movement of viral RNA (28), and symptom formation (20). Depending on the size of the $\mathrm{CP}$-encapsidated viral RNA, virions of AlMV can differ greatly in size (30 to $60 \mathrm{~nm}$ in length and $18 \mathrm{~nm}$ in diameter) and form (spherical, ellipsoidal, or bacilliform).

The host range of AlMV is remarkably wide (7) and includes the agriculturally valuable crops, alfalfa (M. sativa), tomato ( $L y$ copersicon esculentum), lettuce (Lactuca sativa), common bean (Phaseolus vulgaris), potato (Solanum tuberosum), white clover (Trifolium repens), and soybean (Glycine max). The virus is transmitted by mechanical inoculation or by an aphid vector $(7,24)$ and usually does not persist in the host $(4,17,23)$. Symptoms of virus infection vary from yellow necrotic patterns accompanied by leaf malformations and stunting to formation of a mild, light-green mosaic pattern. Symptoms can either persist or disappear soon after infection, depending on the host plant species and environmental conditions.

Corresponding author: V. Yusibov; E-mail address: vyusibov@fraunhofer.org

Publication no. P-2001-0730-02R

(C) 2001 The American Phytopathological Society
Soybean, the most important grain legume crop grown (60 million acres yearly) in the United States, is susceptible to many viruses, including Soybean mosaic virus, Tobacco ringspot virus, Bean yellow mosaic virus, and AlMV. Although the incidence of mosaic diseases is low, diseased plants produce very few seeds and product loss due to infection can be significant (7). In this study, we monitored AlMV pathogenesis and virus accumulation in different parts of greenhouse-grown soybean plants (G. max) throughout the entire growth cycle. Systemically infected leaves showed mild mosaic symptoms that persisted throughout the life cycle. Infection also resulted in stunted growth and decreased seed production. In spite of some reduction in growth and seed production, virus-infected soybean plants can be an excellent source for value-added proteins. Inoculation of soybean plants with recombinant virus containing rabies peptide resulted in the production of full-length chimeric protein that reacted with antibodies specific for AlMV CP and surface glycoprotein of rabies virus.

\section{MATERIALS AND METHODS}

Inoculum preparation. Purified AlMV isolate 425 was provided by S. Loesch-Fries (Purdue University, Lafayette, IN). Stock virus was prepared from the leaves of Nicotiana tabacum cv. Xanthi-nc plants inoculated with AlMV virions diluted in FES buffer (sodium-pyrophosphate [1\%, wt/vol], macaloid [1\%, wt/vol], celite [1\%, wt/vol], $0.5 \mathrm{M}$ glycine, and $0.3 \mathrm{M} \mathrm{K}_{2} \mathrm{HPO}_{4}, \mathrm{pH} 8.5$, with phosphoric acid). Virus was isolated as described (35) at 15 to 20 days after inoculation. Briefly, leaf tissue was ground and the sap separated from cell debris by centrifugation. Virus particles were selectively precipitated with $5 \%$ polyethylene glycol. Purified virus was used to inoculate soybean plants.

In vitro transcripts of AlMV RNAs were synthesized using T7 (for genomic RNAs 1, 2, and 3) or SP6 (for subgenomic RNA4) RNA polymerases (Promega, Madison, WI) and purified plasmid DNA, according to the manufacturer's guidelines. Purified 
plasmid DNAs corresponding to genomic RNAs 1, 2 (pUT17 and pUT27, respectively) (19), and 3 (recRNA3), or subgenomic RNA4 (pSP65A4) (13) of AlMV were linearized with SmaI at the $3^{\prime}$ end of the viral RNA sequences before the in vitro transcription reaction. The reaction was performed in a $100-\mu \mathrm{l}$ volume. Transcripts were capped with the RNA cap structure analog m7G(5)ppp(5)G (Biolabs, Beverly, MA).

Plant growth and infection. Seeds of $N$. tabacum cv. Xanthinc, $N$. benthamiana, and G. max (obtained from R. Muse, Delaware Valley College, Doylestown, PA) were germinated and maintained in the greenhouse for the entire time of study. $N$. tabacum cv. Xanthi-nc and N. benthamiana plants were inoculated with AlMV diluted in FES buffer ( $2 \mathrm{ng} / \mu \mathrm{l})$ (31) by application onto four upper leaves (at six-leaf stage) abraded with Carborundum (320 grit; Fisher, Pittsburgh, PA), followed by gentle rubbing to spread the inoculum and further abrade the leaf surface. Cotyledons and two leaves of 12-day-old soybean seedlings were

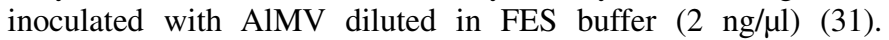
Experiments with soybean plants were performed twice (February through April and September through November 2000) using three separate batches of plants (20 plants per batch) inoculated at 1 -week intervals in each experiment. Virus was isolated from leaves, roots, and seed coats of infected soybean plants (35).

For infection with recombinant AlMV containing chimeric peptide representing regions from rabies virus glycoprotein and nucleoprotein, soybean plants were inoculated with a mixture of in vitro-synthesized transcripts of AlMV genomic RNAs 1, 2, and 3, and subgenomic RNA4. Genomic RNA3 contained nucleotide sequences encoding the rabies peptide, which was cloned and expressed as an in-frame, N-terminal fusion with AlMV CP. To assess the stability of recombinant virus, we prepared extracts from systemically infected leaves of plants (inoculated with a mixture of in vitro synthesized transcripts) at 20 days postinoculation (dpi) and used it as an inoculum for healthy seedlings.

Sample preparation and western blot analysis. Tissue obtained from leaves, roots, seedpods, seeds, seed coats, cotyledons, and embryos were placed in Eppendorf tubes, frozen in liquid nitrogen, ground, and boiled for $10 \mathrm{~min}$ in $2 \times$ loading buffer $(2 \%$ sodium dodecyl sulfate $[\mathrm{SDS}], 10 \%$ glycerol, $5 \% \quad \beta$-mercapto- ethanol, $0.01 \%$ bromophenol blue, and $50 \mathrm{mM}$ Tris- $\mathrm{HCl}, \mathrm{pH}$ 6.8). After centrifugation, supernatants were analyzed for the presence of AlMV CP by western blotting (35). Briefly, proteins were separated electrophoretically on SDS-polyacrylamide gels and electroblotted onto a nitrocellulose membrane for $1 \mathrm{~h}$ at $100 \mathrm{~mA}$. After blocking with $5 \%$ dry milk, proteins were reacted with monoclonal antibodies against AlMV CP conjugated with horseradish peroxidase (Agdia, Elkhart, IN) and detected by the ABC kit (Vector Laboratories, Burlingame, CA) or chemiluminescent substrate (Boehringer, Indianapolis, IN). Recombinant AlMV CP containing chimeric rabies peptide, in addition, was detected with rabies virus $\mathrm{G}$ protein-specific antibodies (35).

To prepare root samples, at $45 \mathrm{dpi}$, AlMV infected or equivalent control soybean plants were removed from their pots, placed in a tray with distilled water, and washed by shaking at room temperature. The washing continued until all soil was removed. After washing was complete, the residual water was removed with paper towels, and roots were used for further experimentation.

To assess the accumulation of virus in leaves at particular times, leaf samples (one leaf per plant at each time) were obtained from the whole batch ( 20 plants per batch). The leaf was taken from the second or third internode from the apex.

Statistics. The average length of internodes in AlMV-infected and healthy plants was calculated at $45 \mathrm{dpi}$. Measurements were taken from three separately infected batches of plants (20 plants per batch). Five plants in each batch were sacrificed to calculate the root mass. The virus yield was averaged from three separate isolations. Standard deviations and $t$ test $(P)$ were calculated using Microsoft Excel version 5.0a for Power Macintosh.

\section{RESULTS}

Symptoms of AIMV infection. Soybean plants showed mosaic symptoms of AlMV infection and yellowing in the upper uninoculated leaves within 10 to $12 \mathrm{dpi}$ (Fig. 1A). These symptoms persisted throughout the life cycle of the plant. In some of the older leaves, the mosaic pattern changed to mold-like symptoms, particularly in the vicinity of main leaf veins (Fig. 1B). Infection resulted in significant stunting of plant growth (Fig. 2), with
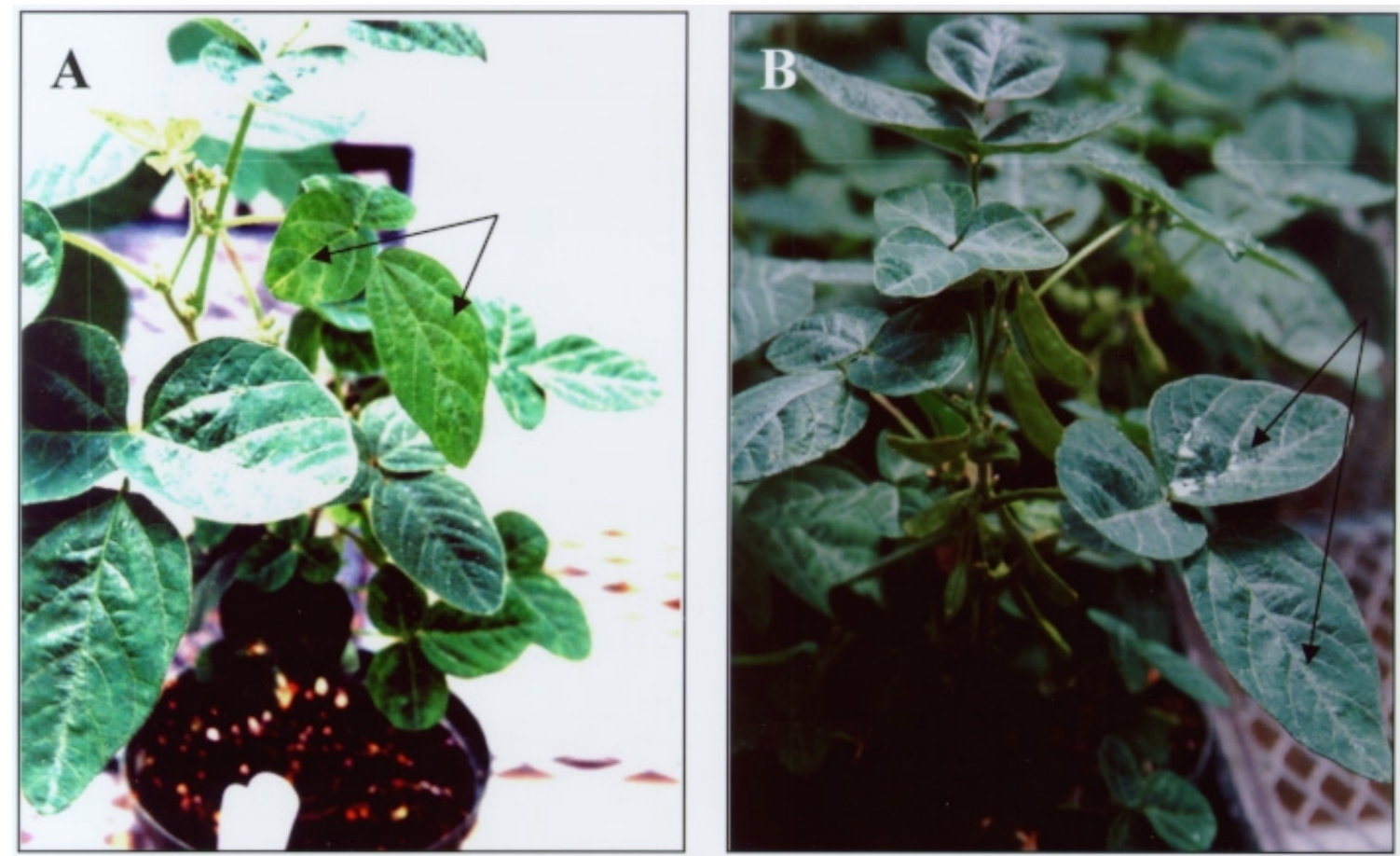

Fig. 1. Symptomotology of Alfalfa mosaic virus infection in soybean plants. A, Accumulation of virus in systemically infected leaves induces mosaic patterns and yellowing (arrows). B, In older leaves, the mosaic develops into mold-like symptoms particularly noticeable along the leaf veins (arrows). 
average length of internodes in AlMV-infected plants calculated at $45 \mathrm{dpi}$, less than half that of control-uninoculated plants $(5.8 \pm$ $0.6 \mathrm{~cm}$ versus $14.2 \pm 0.6 \mathrm{~cm} ; P=0.0001)$ of the same age. Although the length of internodes in infected plants was dramatically reduced, the number of internodes did not change dramatically ( $5 \pm 1$ versus $7 \pm 1 ; P=0.0350$, data collected at 45 dpi). Root mass in infected plants was dramatically reduced compared with that of healthy control plants $(2.8 \pm 0.8 \mathrm{~g}$ versus $9.5 \pm 1.5 \mathrm{~g} ; P=$ 0.0002), and infection decreased leaf size, although the shape of leaves was the same in infected and control plants. In both experiments, symptoms of virus infection were similar, however, there were some differences in the time of flowering and seedpod formation. Whereas plants inoculated in the spring (February through April) flowered and formed seedpods at essentially the same time as did healthy plants, the number of seedpods formed per infected plant was less than that of control plants $(20 \pm 3$ versus $30 \pm 2 ; P=0.004$ ). Plants infected in the fall (September through November) showed a 2-week delay in flowering and pod formation compared with that of healthy control plants. Infection did not significantly affect the number of seeds per pod and mature soybeans harvested from AlMV-infected and control plants were morphologically indistinguishable in both experiments. Together, these findings indicate that symptoms of AlMV infection persist throughout the life cycle of the plant, resulting in significant stunting of growth (reduced internode length), limited root formation, and decreased seed production (up to 35\%). It should be emphasized, however, that when we decreased the amount of virus in the initial inoculum $(0.5 \mathrm{ng} / \mu \mathrm{l})$, the onset of systemic symptoms was delayed and the severity of stunting of plant growth was reduced. Seed production was reduced only up to $25 \%$. Even so, it did not significantly affect overall accumulation of virus in different parts of the plant and time of virus movement from locally inoculated into the upper uninoculated leaves (data not shown).

AIMV CP accumulation in infected plants. Western blot analysis of tissue samples from locally and systemically infected leaves collected at 15 dpi revealed a band of the size expected for the AlMV CP $(24.0 \mathrm{kDa})$, as detected by reactivity with AlMV CP-specific antibodies (Fig. 3A). Similar analysis of a second set of tissue samples from systemically infected leaves and newly forming seedpods collected at $25 \mathrm{dpi}$ also revealed AlMV CP in both tissue types but not in samples from healthy plants (Fig. 3B). By 35 dpi, AlMV CP was detected in fresh beans, in addition to systemically infected leaves and seedpods (Fig. 3C). At 45 dpi, AlMV CP was detected in samples obtained from systemically infected leaves, seedpod, and seed coat (Fig. 3D). At 55 dpi, CP levels in leaf tissue were noticeably decreased (Fig. 3E) and at 65 dpi undetectable (Fig. 3F). Only seedpods and seed coats contained AlMV CP at day 65 (Fig. 3F). Neither cotyledons nor embryos (dissected from five seeds) contained detectable AlMV $\mathrm{CP}$ at any time analyzed. In addition, inoculation of $N$. benthamiana plants with extracts either from cotyledons or embryos never resulted in infection, consistent with the results of western analysis, whereas plants inoculated with extracts from leaves, seedpods, or seed coat all showed AlMV-specific symptoms. In seeds collected from AlMV-infected plants and stored at $4{ }^{\circ} \mathrm{C}$ for 1 year, only seedpods and seed coats contained detectable AlMV CP (data not shown). $N$. benthamiana plants inoculated with extracts of seedpods and seed coats exhibited symptoms of virus infection in both inoculated and upper uninoculated leaves at 10 dpi (data not shown), indicating that the storage period did not dramatically affect AlMV infectivity.

Western analysis of root samples from infected soybean plants revealed the $24.0-\mathrm{kDa}$ protein as detected by reactivity with AlMV CP-specific antibodies (Fig. 4, root-1 and root-2). Similar analysis of roots that had been washed, air dried, and stored at room temperature for 2 weeks also revealed reactivity with the 24.0-kDa protein (Fig. 4, dry-1 and dry-2), indicating the stability of AlMV CP in dried root material. Moreover, N. benthamiana plants inoculated with extracts from dried roots showed AlMVspecific symptoms in locally inoculated and upper uninoculated leaves. Levels of AlMV in systemically infected leaves began to decline after 30 days $(0.9 \pm 0.11,0.5 \pm 0.07$, and $0.2 \pm 0.025 \mathrm{mg}$ of AlMV recovered per gram of fresh leaf tissue at 30, 45, and 55 dpi, respectively), whereas the amount of virus recovered from seedpod $(0.6 \pm 0.09 \mathrm{mg} / \mathrm{g}$ of fresh tissue $)$ and seed coat $(0.93 \mathrm{mg} / \mathrm{g}$ of fresh tissue; material combined from three experimental batches) remained high even at 70 dpi. AlMV could be recovered from roots at $65 \mathrm{dpi}(0.15 \pm 0.03 \mathrm{mg} / \mathrm{g}$ of root tissue $)$ by the standard procedure used to isolate AlMV from leaf tissue.

Seedlings germinated from virus-infected plants contained no detectable AlMV, consistent with the absence of detectable virus in viable embryos or cotyledons. CP-positive seedpods and seed coats do not become a part of newly germinated seedlings and, thus, do not normally transmit virus to seedlings, which is in agreement with early reports (24).

Cloning and expression of foreign sequences fused with AlMV CP in soybean plants. Chimeric peptide, representing rabies virus glycoprotein (amino acids 253-275) and nucleoprotein (amino acids 404-418), which induce protective immunity in animals (35), is an excellent candidate for subunit vaccine development. DNA sequences coding for 38 amino acid peptide were polymerase chain reaction (PCR) amplified using two primers, with 15 overlapping nucleotides that served as a template for each other. The resulting PCR product was digested utilizing artificially created restriction sites (XhoI at $5^{\prime}$ and SalI at $3^{\prime}$ ends) and cloned into the open reading frame of AlMV CP in pSPAAUG (33) using an $\mathrm{XhoI}$ site. After sequence confirmation, the chimeric AlMV RNA4 containing sequences encoding rabies peptide was introduced into full-length infectious RNA3 (Fig. 5) that was utilized as an expression vector. Translation of recombinant $\mathrm{CP}$ in recRNA3 (Fig. 5) starts from the ATG codon introduced at the 5' end of the DNA sequences encoding the chimeric rabies peptide.

Soybean plants were inoculated with the mixture of in vitrosynthesized transcripts of recRNA3 (containing coding sequences

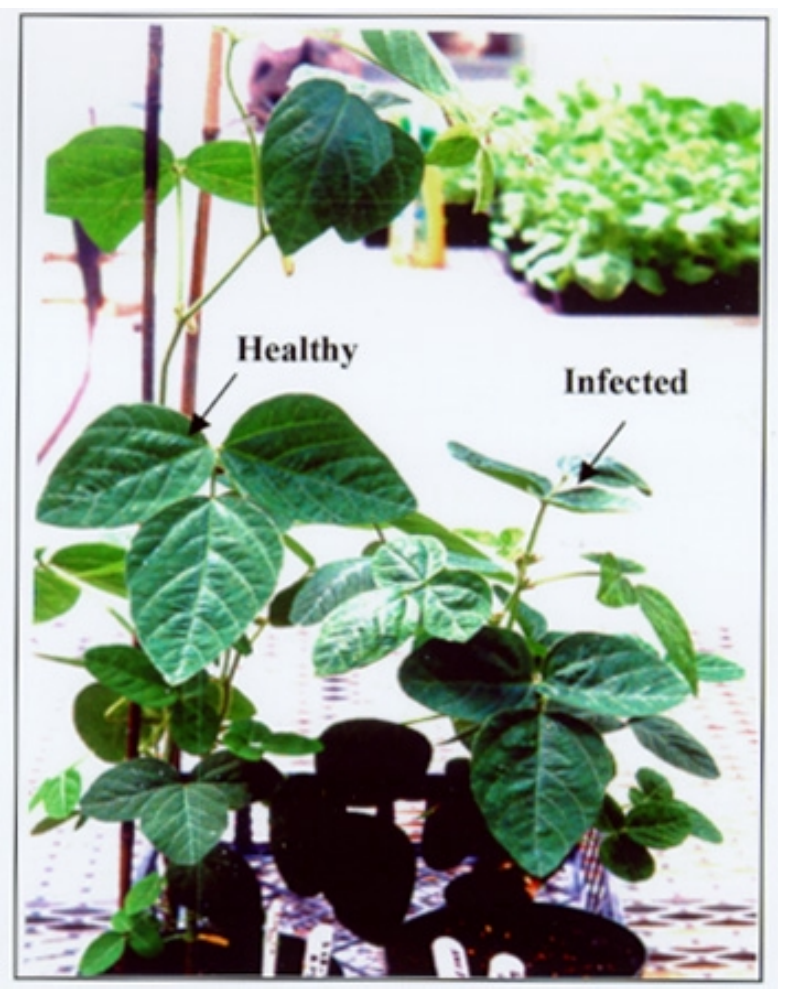

Fig. 2. Comparison of Alfalfa mosaic virus-infected soybean plants and noninfected control plants (healthy). Note the stunted growth of the infected plant. 
for AlMV CP fused with the 38 amino acid peptide from rabies virus), RNA1, RNA2, and RNA4. At 10 to $12 \mathrm{dpi}$, mild mosaic symptoms of virus infection were observed in the upper uninoculated leaves. Infection with the recombinant virus resulted in stunting of plant growth similar, but not as severe, to that observed after wild-type AlMV infection. Western blot analysis of infected leaf samples at 15 dpi demonstrated expression of recombinant protein in the systemically infected leaves, with antibodies specific for AlMV CP (Fig. 6A) and for rabies virus glycoprotein (Fig. 6B) revealing the expected size protein $(29.3 \mathrm{kDa})$. Wild-type AlMV CP reacted only with AlMV CP-specific antibodies and not with antibodies specific for rabies virus glycoprotein (Fig. 6A and B). After western blot analysis, extracts from systemically infected leaves of these plants were used to inoculate a new batch of healthy soybean seedlings. At 30 and 70 dpi (time when the optimum amount of fresh seed coat tissue containing highest quantity of virus can be recovered), the recombinant virus was isolated from systemically infected leaves $(0.5 \mathrm{mg} / \mathrm{g}$ of fresh tissue) or seed coat $(0.62 \mathrm{mg} / \mathrm{g}$ of fresh tissue $)$ of newly infected plants, respectively, and assessed by western blot analysis (Fig. 6C). The optimal time of recombinant virus purification was determined based on our observations of AlMV accumulation in infected soybean plants. As shown in Figure 6, panel $\mathrm{C}$, virus isolated from both leaves and seed coat contain expected size protein $(29.3 \mathrm{kDa})$ that reacts with AlMV
CP-specific antibodies. Recovery of virus consisting of the fullsize recombinant protein from systemically infected leaves and seed coat, after virus was passaged from plants inoculated with in vitro-synthesized transcripts, demonstrated the stability of the engineered construct and usefulness of soybean as production host. Recombinant protein was also detected in roots and seedpods of infected plants (data not shown), suggesting the potential usefulness of each of these organs for producing value-added proteins.

\section{DISCUSSION}

Knowledge of the disease process induced by plant pathogens in a particular host is a first step toward developing appropriate control measures, including the introduction of pathogen-resistant traits (1). This information is also useful when developing viral vectors for foreign gene expression, because the location and the levels of virus accumulation will often reflect the location and levels of foreign protein accumulation.

Information about the pathogenicity of this virus in host species other than $M$. sativa has been limited. We studied the susceptibility of soybean plants to AlMV infection under greenhouse conditions, as well as the overall effects of AlMV-induced disease on plant growth, flowering, and seed production. Greenhousegrown soybean plants were highly susceptible to virus infection
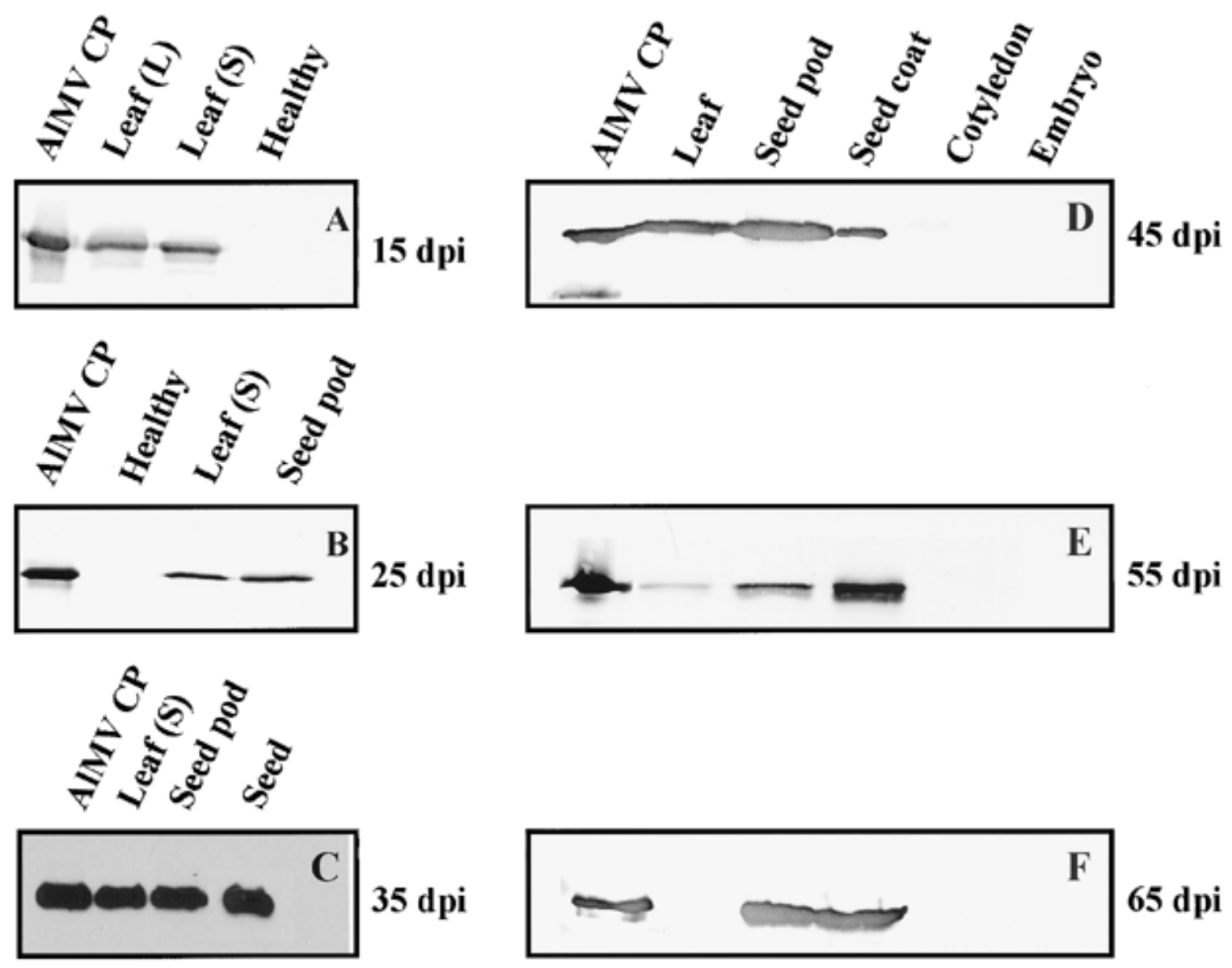

Fig. 3. Western blot analysis of coat protein (CP) expression in soybean plants infected with wild-type Alfalfa mosaic virus (AlMV). Proteins were separated electrophoretically on a $12 \%$ sodium dodecyl sulfate-polyacrylamide gel, transferred to a membrane, and reacted with monoclonal antibodies specific for AlMV CP. Antibodies recognized the expected size protein ( $24.0 \mathrm{kDa}$ ) in samples collected on $\mathbf{A}, 15$ and $\mathbf{B}$, 25 days postinoculation (dpi) from locally (L) inoculated and systemically (S) infected leaves as well as in newly forming seedpods. Extracts from uninoculated control plants (Healthy) showed no product. C, Samples obtained from systemically infected leaf, seedpod, and seed at 35 dpi all revealed AlMV CP. D to F, Samples were obtained from systemically infected leaf, seedpod, seed coat, cotyledon, and embryo at 45, 55, and 65 dpi, respectively; AlMV CP was detected at each time point in samples from seedpod and seed coat, and up to 55 dpi in samples from leaf tissue. AlMV CP was not detected in samples from cotyledon and embryo. In all panels, AlMV CP from purified virus was used as a positive control. 
during the first 2 to 3 weeks after germination. Within 8 to 10 days after inoculation, virus moved to the upper uninoculated leaves, establishing systemic infection that persisted, in some parts of plants, throughout the life cycle of the plant and accumulated in leaves, roots, seedpod, and seed coats. The spread of virus resulted in mild mosaic symptoms in systemically infected leaves without additional leaf deformation. However, the infection caused stunting of plant growth, limited root formation, and decreased seed production (up to $35 \%$ ).

Some plant RNA viruses do not replicate continuously in all host species, and infection may not persist throughout the life cycle of the plant. For example, in AlMV-infected tobacco plants, virus concentrations are highest at 15 to 20 days after inoculation, declining and even clearing thereafter (23). Our soybean plants supported high levels of AlMV replication in leaf tissue up to 30 days before a gradual decrease. Only after 65 days (mature seed stage) was AlMV CP no longer detected in leaf samples by western blot analysis. However, significant quantities of virus

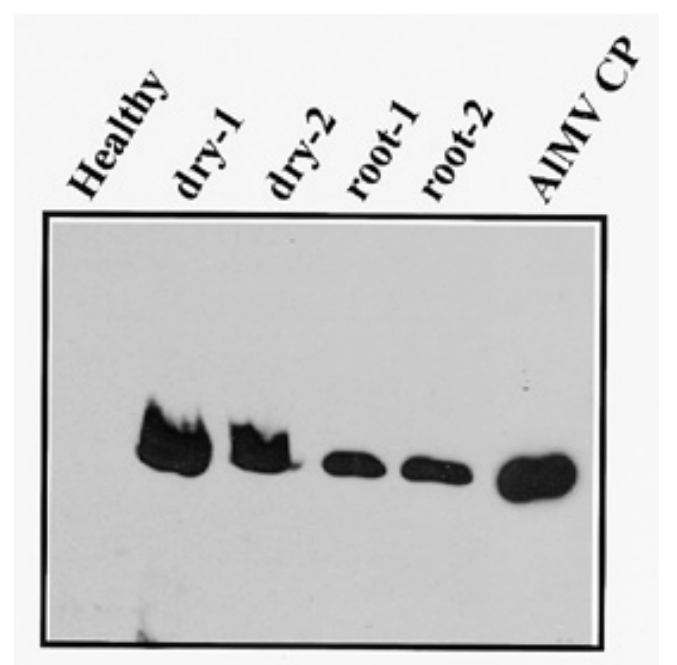

Fig. 4. Western blot analysis of coat protein (CP) expression in roots of soybean plants infected with wild-type Alfalfa mosaic virus (AlMV). Proteins were separated electrophoretically on a $12 \%$ sodium dodecyl sulfate-polyacrylamide gel, transferred to a membrane, and reacted with monoclonal antibodies specific for AlMV CP. Antibodies recognized the expected size protein $(24.0 \mathrm{kDa})$ in samples from fresh roots (root-1 and root-2) as well as in root tissue dried and stored at room temperature (dry-1 and dry-2). Antibodies did not react with any proteins in root extracts from control (Healthy) plants. AlMV CP from purified virus was used as a positive control. were detected in seed coat and seedpod even after 1 year of storage at $4^{\circ} \mathrm{C}$, and the virus remained infectious as observed in $N$. benthamiana plants. No morphological differences between seeds from healthy and AlMV-infected plants were observed, except in very few seeds that had deformed seed coats.

In recent years, plants have been actively targeted for the production of medically important proteins, including vaccine antigens and monoclonal antibodies (11). A variety of antigens have been expressed in transgenic plants, including hepatitis B surface antigen (15), Escherichia coli heat-labile enterotoxin (10), rabies virus glycoprotein (16), and Norwalk virus capsid protein (14). In addition to transgenic plants, viruses that infect plants have been used as an alternative approach to express high levels of foreign proteins $(5,9,18,22,26,27,35)$. An important aspect of using plant viruses as production tools is screening and establishing appropriate host species for manufacturing large quantities of polypeptides. Depending on the specific product and target population, it is important to use the appropriate plant species with targeted expression of the product in different parts of the plant (leaves, roots, or seeds). The present study suggests the usefulness of soybean plants as a vehicle for producing biomedical reagents utilizing an AlMV-based expression vector. If the leaf tissue is the source of biomedicals, a period of 30 days is sufficient to obtain the highest accumulation of virus at maximum yield of biomass. Alternatively, roots, seeds, or seedpods can be targeted as the source of product and can be stored and distributed relatively easily. In fact, because the virus accumulates in readily separated seed coat, this portion of the plant might provide a rich source of value-added proteins. Indeed, we have demonstrated that sufficient quantities of recombinant virus containing chimeric rabies peptide can be recovered from systemically infected leaves $(0.5 \mathrm{mg} / \mathrm{g}$ of fresh tissue) at $30 \mathrm{dpi}$ and from seed coat $(0.62 \mathrm{mg} / \mathrm{g}$ of fresh tissue) at $70 \mathrm{dpi}$. In addition, rabies/foreign sequences fused to AlMV CP can be recovered in a very cost-effective manner utilizing standard virus isolation procedure. Introduction of foreign sequences, however, have resulted in some attenuation of virus accumulation and severity of symptoms. For example, the yield of recombinant AlMV compared with that of wild-type AlMV in systemically infected leaves $(0.9 \pm 0.11 \mathrm{mg} / \mathrm{g}$ of fresh tissue) at $30 \mathrm{dpi}$ or seed coat $(0.93 \mathrm{mg} / \mathrm{g}$ of fresh tissue $)$ at $70 \mathrm{dpi}$ is 35 to $40 \%$ lower. Reduction of symptom severity, however, results in the accumulation of larger amounts of source material (leaves, roots, seedpod, and seed coats). Thus, considering the quantities of virus we are able to recover, utilizing a very economical procedure (virus isolation), this approach has great potential for producing foreign sequences in soybean plants in a safe, time- and cost-efficient manner.

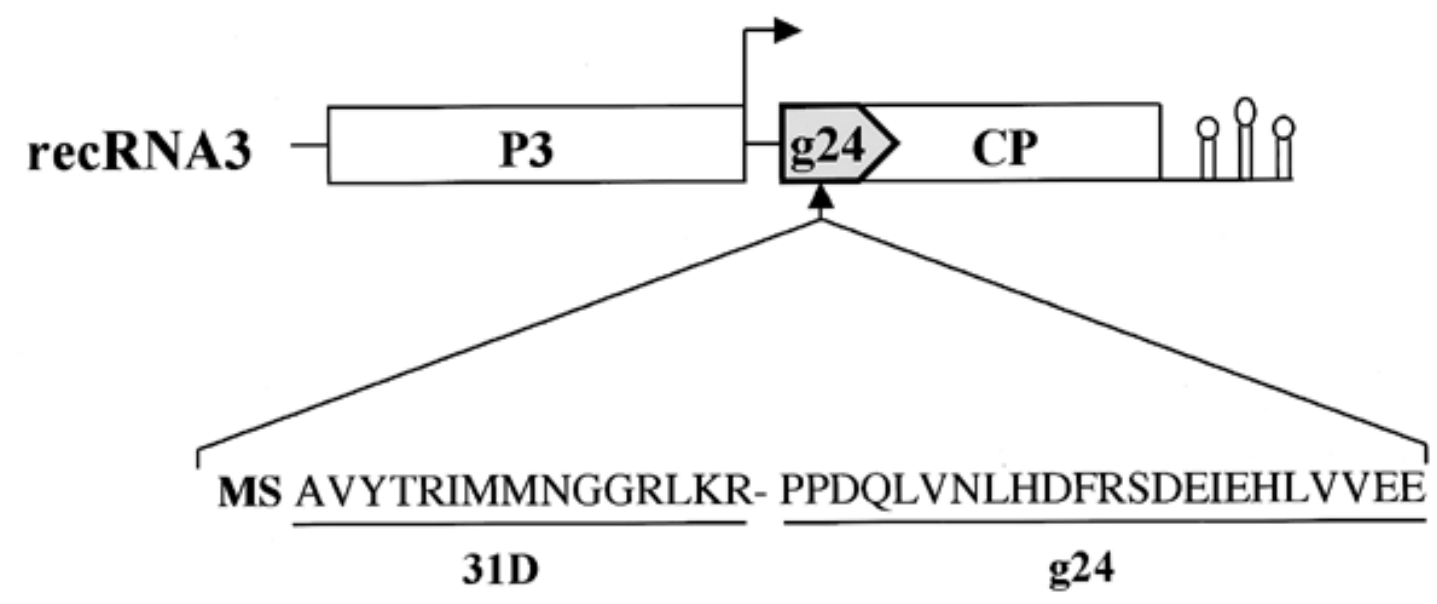

Fig. 5. Schematic representation of Alfalfa mosaic virus RNA3 (recRNA3) encoding a coat protein (CP) gene fused with the sequences encoding chimeric rabies peptide. P3, cell-to-cell movement protein. Arrow indicates the subgenomic promoter for RNA4. 31D is a peptide (T cell epitope) from rabies nucleoprotein. g24 is a peptide (B cell epitope) from rabies virus glycoprotein. Amino acid sequences of the rabies peptides are indicated in the text. 


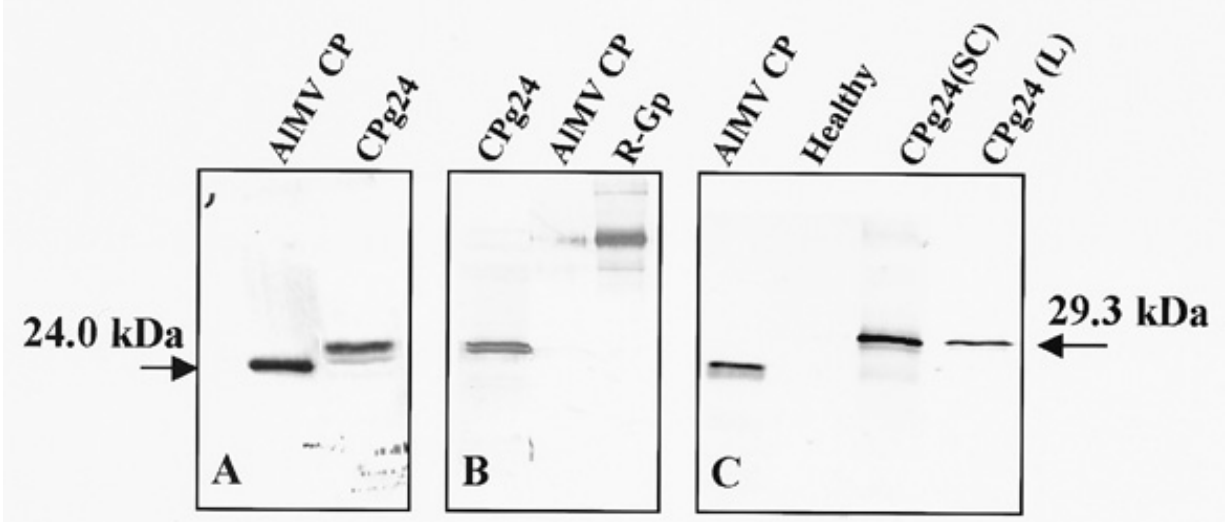

Fig. 6. Western blot showing accumulation of recombinant Alfalfa mosaic virus (AIMV) coat protein (CP) (Cpg24) fused to rabies virus peptide in A and B, systemically infected soybean leaves, and $\mathbf{C}$, virus samples isolated from systemically infected leaves or seed coat. A and $\mathbf{B}$, Leaves were inoculated with in vitro-synthesized transcripts of recombinant virus. At 10 to 12 days postinoculation (dpi), samples from systemically infected leaves were collected, and proteins were separated by electrophoresis on a 12\% sodium dodecyl sulfate (SDS)-polyacrylamide gel and reacted with monoclonal antibodies specific for A, the AIMV CP, or C, the linear epitope (G5-24) of rabies virus glycoprotein (R-Gp, purified rabies virus glycoprotein $60 \mathrm{kDa})$. C, Plants were inoculated with extracts passaged from systemically infected soybean leaves. Recombinant virus was purified from systemically infected leaves at $30 \mathrm{dpi}[\mathrm{CPg} 24(\mathrm{~L})]$ and seed coat at $70 \mathrm{dpi}[\mathrm{CPg} 24(\mathrm{SC})]$. Samples of purified virus were separated by electrophoresis on a $12 \%$ SDS-polyacrylamide gel and reacted with monoclonal antibodies specific for the AIMV CP, revealing expected size $(29.3 \mathrm{kDa})$ protein in preparations from both leaves and seed coat. Wild-type AIMV CP (24 kDa) reacted only with $\mathbf{A}$ and $\mathbf{C}$, antibodies against AIMV CP, and $\mathbf{B}$, not with antibodies against rabies peptide. C, Extracts from healthy plants did not react with antibodies against AlMV CP.

\section{ACKNOWLEDGMENTS}

This study at the Biotechnology Foundation Laboratories was supported by a grant from the Commonwealth of Pennsylvania and the U.S. Department of Agriculture (Agricultural Research Service). We thank R. Hammond for critical reading of this manuscript, S. Loesch-Fries for the original AlMV sample, and G. Golovin and M. Bertovich for technical help.

\section{LITERATURE CITED}

1. Beachy, R. N., Loesch-Fries, S., and Tumer, N. E. 1990. Coat protein mediated resistance against virus infection. Annu. Rev. Phytopathol. 28:451-474.

2. Bol, J. F. 1999. Alfalfa mosaic virus and ilarviruses: Involvement of coat protein in multiple steps of the replication cycle. J. Gen. Virol. 80:10891102.

3. Bol, J. F., van Vloten-Doting, L., and Jaspars, E. M. 1971. A functional equivalence of top component a RNA and coat protein in the initiation of infection by alfalfa mosaic virus. Virology 46:73-85.

4. Brink, G. E., and McLaughlin, M. R. 1990. Influence of seeding rate and interplanting with tall fescue on virus infection of white clover. Plant Dis. 74:51-53.

5. Dalsgaard, K., Uttenthal, A., Jones, T. D., Xu, F., Merryweather, A., Hamilton, W. D. O., Langeveld, J. P. M., Boshuizen, R. S., Kamstrup, S., Lomonossoff, G. P., Porta, C., Vela, C., Casal, J. I., Meloen, R. H., and Rodgers, P. B. 1997. Plant-derived vaccine protects target animals against a viral disease. Nature Biotech. 15:248-252.

6. de Graaff, M., Man in't Veld, M. R., and Jaspars, E. M. 1995. In vitro evidence that the coat protein of alfalfa mosaic virus plays a direct role in the regulation of plus and minus RNA synthesis: Implications for the life cycle of alfalfa mosaic virus. Virology 208:583-589.

7. Dunleavy, J. M. 1973. Viral diseases. Pages 505-526 in: Soybeans: Improvement, Production, and Uses. B. E. Caldwel, ed. The American Society of Agronomy, Madison, WI.

8. Erny, C., Schoumacher, F., Jung, C., Gagey, M.-J., Godefroy-Colburn, T., Stussi-Garaud, C., and Berna, A. 1992. An N-proximal sequence of the alfalfa mosaic virus movement protein is necessary for association with cell walls in transgenic plants. J. Gen. Virol. 73:2115-2119.

9. Hamamoto, H., Sugiyama, Y., Nakagawa, N., Hashida, E., Matsunaga, Y., Takemoto, S., Watanabe, Y., and Okada, Y. 1993. A new tobacco mosaic virus vector and its use for the systemic production of angiotensin-I-converting enzyme inhibitor in transgenic tobacco and tomato. Bio/Technology 11:930-932.

10. Haq, T. A., Mason, H., Clements, J. D., and Arntzen, C. J. 1995. Oral immunization with a recombinant bacterial antigen produced in transgenic plants. Science 268:714-716.

11. Hiatt, A., Cafferkey, R., and Bowdish, K. 1989. Production of antibodies in transgenic plants. Nature 342:76-78.
12. Jaspars, E. M. 1974. Plant viruses with a multipartite genome. Adv. Virus Res. 19:37-149.

13. Loesch-Fries, L. S., Jarvis, N. P., Krahn, K. J., Nelson, S. E., and Hall, T. C. 1985. Expression of alfalfa mosaic virus RNA4 cDNA transcripts in vitro and in vivo. Virology 146:177-187.

14. Mason, H. S., Ball, J. M., Shi, J. J., Jiang, X., Estes, M. K., and Arntzen, C. J. 1996. Expression of Norwalk virus capsid protein in transgenic tobacco and potato and its oral immunogenicity in mice. Proc. Natl. Acad. Sci. USA 93:5335-5340.

15. Mason, H. S., Lam, D. M.-K., and Arntzen, C. J. 1992. Expression of hepatitis B surface antigen in transgenic plants. Proc. Natl. Acad. Sci. USA 89:11745-11749.

16. McGarvey, P. B., Hammond, J., Dienelt, M. M., Hooper, D. C., Fu, Z. F., Dietzschold, B., Koprowski, H., and Michaels, F. H. 1995. Expression of the rabies virus glycoprotein in transgenic tomatoes. Bio/Technology 13: 1484-1487.

17. McLaughlin, M. R. 1991. A greenhouse method for aphid inoculation of alfalfa mosaic virus in white clover by co-culture of virus, vector, and clover. Page 318 in: Aphid Plant Interaction: Populations to Molecules. D. C. Peters, J. A. Webster, and C. S. Chlouber, eds. Okla. Agric. Exp. Stn., Stillwater, OK.

18. Modelska, A., Dietzschold, B., Fu, Z. F., Steplewski, K., Hooper, D. C., Koprowski, H., and Yusibov, V. 1998. Immunization against rabies with plant-derived antigen. Proc. Natl. Acad. Sci. USA 95:2481-2485.

19. Neeleman, L., and Bol, J. F. 1999. Cis-acting functions of alfalfa mosaic virus proteins involved in replication and encapsidation of viral RNA. Virology 254:323-333.

20. Neeleman, L., van der Kuyl, A. C., and Bol, J. F. 1991. Role of alfalfa mosaic virus coat protein gene in symptom formation. Virology 181:687693.

21. Neeleman, L., van der Vossen, E. A., and Bol, J. F. 1993. Infection of tobacco with alfalfa mosaic virus cDNAs sheds light on the early function of the coat protein. Virology 196:883-887.

22. Porta, C., Spall, V. E., Loveland, J., Johnson, J. E., Barker, P. J., and Lomonossoff, G. P. 1994. Development of cowpea mosaic virus as a high-yielding system for the presentation of foreign peptides. Virology 202:949-955.

23. Ross, A. F. 1941. The concentration of alfalfa-mosaic virus in tobacco plants at different periods of time after inoculation. Phytopathology 31:410-420.

24. Ross, A. F. 1973. Viral and bacterial diseases. Pages 729-755 in: Soybeans: Improvement, Production, and Uses. B. E. Caldwel, ed. The American Society of Agronomy, Madison, WI.

25. Stussi-Garaud, C., Garaud, J.-C., Berna, A., and Godefroy-Colburn, T. 1987. In situ location of an alfalfa mosaic virus non-structural protein in plant cell walls: Correlation with virus transport. J. Gen. Virol. 68:17791784.

26. Turpen, T. H., Reini, S. J., Charoenvit, Y., Hoffman, S. L., Fallarme, V., and Grill, L. K. 1995. Malarial epitopes expressed on the surface of recombinant tobacco mosaic virus. Bio/Technology 13:53-57. 
27. Usha, R., Rohll, J. B., Spall, V. E., Shanks, M., Maule, A. J., Johnson, J. E., and Lomonosoff, G. P. 1993. Expression of an animal virus antigenic site on the surface of a plant virus particle. Virology 197:366-374.

28. van der Kuyl, A. C., Neeleman, L., and Bol, J. F. 1991. Complementation and recombination between alfalfa mosaic virus RNA3 mutants in tobacco plants. Virology 183:731-738.

29. van der Kuyl, A. C., Neeleman, L., and Bol, J. F. 1991. Role of alfalfa mosaic virus coat protein in regulation of the balance between viral plus and minus strand RNA synthesis. Virology 185:496-499.

30. van der Vossen, E. A., Neeleman, L., and Bol, J. F. 1994. Early and late functions of alfalfa mosaic virus coat protein can be mutated separately. Virology 202:891-903.

31. Verch, T., Yusibov, V., and Koprowski, H. 1998. Expression and assem- bly of a full-length monoclonal antibody in plants using a plant virus vector. J. Immunol. Methods 220:69-75.

32. Weimer, J. L. 1931. Alfalfa mosaic. Phytopathology 21:122.

33. Yusibov, V., and Loesch-Fries, L. S. 1995. N-terminal basic amino acids of alfalfa mosaic virus coat protein involved in the initiation of infection. Virology 208:405-407.

34. Yusibov, V., and Loesch-Fries, L. S. 1998. Functional significance of three basic $\mathrm{N}$-terminal amino acids of alfalfa mosaic virus coat protein. Virology 242:1-5

35. Yusibov, V., Modelska, A., Steplewski, K., Agadjanyan, M., Weiner, D., Hooper, C., and Koprowski, H. 1997. Antigens produced in plants by infection with chimeric plant viruses immunize against rabies virus and HIV-1. Proc. Natl. Acad. Sci. USA 94:5784-5788. 